\title{
PENGARUH STATUS HUBUNGAN BERPACARAN TERHADAP PERILAKU PACARAN BERISIKO PADA MAHASISWA PERANTAU ASAL PAPUA DI KOTA SURABAYA
}

\author{
Christine Ohee ${ }^{1)}$, Windhu Purnomo ${ }^{2)}$ \\ ${ }^{1,2}$ Departemen Biostatistika dan Kependudukan, \\ Fakultas Kesehatan Masyarakat, Universitas Airlangga \\ Alamat Korespondensi: Christine Ohee \\ Email: christineitin26@gmail.com
}

\begin{abstract}
The quality of education in eastern part of Papua is still low so that many teenagers choose to go out the Papua for study. One of the factors of risky sexual behavior among adolescents students is wandered. The risky dating behavior of Papuan students in Surabaya is 76.7\%. The purpose of this study is to analyze the impact of dating status with the risky dating behavior among Papuan origin students in Surabaya. This research is an observational analytic research with cross sectional design. The research population was 260 migrant college students from Papua. The research sample was 70 male and female college students. The independent variables of this research were age, sex, relationship status, intention of risky dating behavior, and knowledge level. The statistical analysis were using multiple logistic regression test with the significance level of 5\%. The result of this research showed that relationship status influenced college students' risky dating behavior $(p=0.001)$, while age, sex, intention of risky dating behavior and knowledge level did not influence college students' risky dating behavior ( $p>0.05)$. The conclusion of the research is the status of dating relationship has an effect on the risky courtship behavior of Papuan native students in Surabaya city. Therefore, students are advised not to date during the study period.
\end{abstract}

Keywords : influence, dating risky behavior, wandering college students, dating status.

\begin{abstract}
ABSTRAK
Kualitas pendidikan di daerah timur Indonesia khususnya Provinsi Papua masih sangat kurang sehingga banyak remaja yang memilih untuk merantau ke luar Pulau untuk melanjukan studi. Merantau menjadi salah satu faktor yang mempengaruhi perilaku seksual berisiko pada remaja khususnya mahasiswa. Demikian pula perilaku pacaran berisiko mahasiswa perantau asal Papua di Kota Surabaya. Tujuan penelitian ini adalah mengetahui pengaruh status hubungan berpacaran terhadap perilaku pacaran berisiko pada mahasiswa perantau asal Papua di Kota Surabaya. Penelitian ini merupakan penelitian observasional analitik dengan rancang cross sectional. Populasi penelitian adalah 260 mahasiswa perantau asal Papua. Sampel penelitian sebesar 70 mahasiswa lakilaki dan perempuan. Variabel bebas penelitian ini adalah, usia, jenis kelamin, status hubungan, niat perilaku pacaran berisiko, dan tingkat pengetahuan. Analisis statistik menggunakan uji regresi logistik ganda dengan tingkat signifikansi 5\%. Hasil penelitian menunjukkan bahwa status hubungan $(p=0,001)$ mempengaruhi perilaku pacaran berisiko mahasiswa, sedangkan usia, jenis kelamin, niat perilaku pacaran berisiko, dan tingkat pengetahuan tidak mempengaruhi perilaku pacaran berisiko mahasiswa $(p>0,05)$. Kesimpulan dari penelitian adalah status hubungan berpacaran berpengaruh terhadap perilaku pacaran berisiko mahasiswa perantau asal Papua di Kota Surabaya. Mahasiswa disarankan untuk tidak berpacaran selama masa studi.
\end{abstract}

Kata kunci : pengaruh, status hubungan pacaran, perilaku pacaran berisiko, mahasiswa perantau

\section{PENDAHULUAN}

Remaja adalah penduduk dalam rentang usia 10-19 tahun (WHO). Terdapat 43,5 juta atau sekitar $18 \%$ remaja usia 10 19 tahun dari jumlah penduduk total di Indonesia (Sensus Penduduk, 2010). Remaja merupakan salah satu penyumbang tingginya populasi bangsa Indonesia. Remaja dimulai dari saat SMP/sederajat, SMA/Sederajat, hingga perguran tinggi. Mayoritas remaja yang lulus dari Sekolah Menengah Atas atau sederajat memilih untuk melanjutkan pendidikan ke jenjang yang lebih tinggi yaitu perguruan tinggi. Mahasiswa adalah seseorang yang sedang 
dalam proses menimba ilmu ataupun belajar dan terdaftar sedang menjalani pendidikan pada salah satu perguruan tinggi yang terdiri dari akademik, politeknik, sekolah tinggi, institut dan universitas (Hidayangsih, 2014). Perguruan tinggi yang berkualitas menjadi pilihan utama bagi pelajar yang tamat sekolah menengah atas. Bukan hanya kualitas yang dilihat, letak geografis wilayah suatu perguruan tinggi juga menjadi faktor pertimbangan dalam pemilihan perguruan tinggi. Banyak mahasiswa perantau yang berasal dari luar kota yaitu dari Sabang sampai Merauke memilih Kota Surabaya untuk berkuliah. Terdapat 500 putra-putri asli Papua yang mendpatkan beasiswa setiap tahunnya untuk melanjutkan pendidikan di 10 Universitas di Pulau Jawa (DIKTI/ADIK, 2015). Universitas yang berada di Jawa Timur khususnya Kota Surabaya yang menjadi pilihan beasiswa ADIK yaitu Universitas Airlangga, Universitas Negeri Surabaya, dan Institute Sepuluh November. Sampai tahun 2015, beasiswa ADIK sudah diberikan kepada 1487 mahasiswa, yakni 1218 mahasiswa yang sedang menempuh pendidikan tinggi di 39 PTN Luar Papua dan 269 mahasiswa sedang berkuliah di Papua. Slain penerima beasiswa, banyak mahasiswa yang berada di perguruan tinggi di Kota Surabaya dengan biaya sendiri atau tanggungan orang tua

Remaja cenderung memilih untuk berpacaran ketika berada di bangku perkuliahan, demikian pula dengan mahasiswa yang merantau. Perilaku pacaran mahasiswa perantau dapat dipengaruhi oleh kebebasan saat merantau. Perilaku pacaran yang dimaksud adalah perilaku pacaran yang berisiko dan yang tidak berisiko. Kebebasan yang dimaksud adalah kurang mendapat pengawasan langsung dari orang tua, kebebasan dalam memilih teman dan lingkungan, dan juga bebas menjalin hubungan asmara bersama lawan jenis.
Berdasarkan hasil survei kesehatan reproduksi remaja, remaja Indonesia pertama kali pacaran pada usia 15-17 tahun. sekitar $33,3 \%$ remaja perempuan dan $34,5 \%$ remaja laki-laki yang berusia 15-19 tahun mulai berpacaran pada saat mereka belum berusia 15 tahun. 92\% remaja berpegangan tangan saat pacaran, $82 \%$ berciuman, $63 \%$ rabaan petting. perilaku-perilaku tersebut kemudian memicu remaja melakukan hubungan seksual (Riskesdas, 2013). Di Indonesia $62,7 \%$ remaja sudah pernah melakukan hubungan seksual dengan lawan jenisnya dan $21 \%$ dari remaja yang hamil diluar nikah pernah melakukan aborsi (Survei oleh KPAI dan Kemenkes Tahun 2013). Hasil Survei Demografi dan Kesehatan Indonesia (SDKI) 2012 menyatakan terjadi peningkatan hubungan seks pranikah pada remaja usia 15-24 tahun dibanding tahuntahun sebelumnya. Hubungan seksual terbanyak dilakukan pada remaja usia 2024 tahun sebesar $9,9 \%$, dan $2,7 \%$ pada usia 15-19 tahun. Salah satu faktor penyebab hubungan seks pra nikah adalah perilaku pacaran remaja. Menurut Survei Kesehatan Reproduksi Remaja (SKRRI) 2012 menunjukkan $28 \%$ remaja pria dan $27 \%$ remaja wanita menyatakan bahwa mereka memulai berpacaran sebelum berumur 15 tahun, sedangkan menurut SKRRI tahun 2007 hanya 19\% remaja pria dan 24\% remaja wanita memulai berpacaran sebelum berumur 15 tahun. 30\% remaja pria dan $6 \%$ remaja wanita melakukan aktivitas meraba/merangsang bagian tubuh yang sensitif pada saat pacaran. Survei Indikator Kinerja Rencana Pembangunan Jangka Menengah Nasional (RPJMN) tahun 2014 menunjukan terdapat $77 \%$ remaja pria dan $76 \%$ remaja wanita pernah berpacaran dan $5,6 \%$ diantara remaja tersebut telah melakukan hubungan seksual sebelum nikah, angka ini lebih tinggi dibanding tahun 2013 yaitu 3,6\% dan tahun 2012 yaitu 2,5\% (Riskesdas, 2013).

Data mengenai perilaku pacaran berisiko pada remaja di Indonesia juga 
merujuk pada remaja di Provinsi Papua. Perilaku pacaran berisiko pada remaja Papua juga tinggi, hal ini dapat dilihat dari dampak perilaku pacaran berisiko remaja Papua yaitu Papua menjadi provinsi dengan penderita HIV/AIDS tertinggi di Indonesia. Data Kementrian Kesehatan hingga September 2014, menunjukkan jumlah kumulatif HIV dan AIDS di Papua masing-masing 16.051 dan 10.184 kasus. Fenomena ini bukanlah hal yang mengherankan mengingat kondisi geografis Papua yang cukup jauh sehingga akses pendidikan di Papua sangat terbatas. Namun, melalui usaha dan kerja keras pemerintah untuk mengurangi angka HIV/AIDS di Papua melalui programprogram penyuluhan tentang pentingnya kesehatan terutama kesehatan seksual, penularan HIV/AIDS di Papua mulai menurun. Data Komisi Penanggulangan AIDS Nasional menyebutkan, prevalensi penularan HIV/AIDS di Papua turun menjadi 2,3 persen pada 2013 dari pendataan terakhir 2007 yang mencapai 2,4 persen (Lestary, 2014). Penelitian Giay (2017) mengenai perilaku seksual mahasiswa Papua di Kota Surabaya menyatakan bahwa proporsi responden laki-laki yang melakukan perilaku seksual berisiko sebesar $63,3 \%$ dan responden perempuan sebesar $34,8 \%$.

Hasil penelitian yang telah diuraikan diatas menjadi dasar penelitian ini, yaitu perilaku seksual mahasiswa, khususnya mahasiswa asal Papua di Kota Surabaya. Selain data yang ada, penelitian ini diperkuat dengan adanya studi pendahuluan dengan metode observasi yang dilakukan pada bulan Oktober 2108 menunjukkan bahwa perilaku pacaran remaja di Papua mengakibatkan tingginya KTD di Papua, pernikahan dini, dan tingginya angka HIV/AIDS di Provinsi Papua. Observasi selama penelitian juga menunjukkan tingginya perilaku seksual berisiko pada mahasiswa dan ada lebih dari satu kasus mahasiswa Papua mengalami kehamilan yang tidak diinginkan (KTD). Demikian hal tersebut menudukung untuk dilakukan penelitian dengan judul pengaruh status hubungan berpacaran terhadap perilaku pacaran berisiko pada mahasiswa perantau asal Papua di Kota Surabaya.

\section{METODE PENELITIAN}

Penelitian ini merupakan penelitian dengan metode kuantitatif, dengan jenis penelitian analitik. Rancang bangun penelitian dengan menggunakan rancangan cross sectional karena data variabel independen dan variabel dependen dikumpukan dalam kurun waktu yang bersamaan dan dilakukan hanya satu kali. (Angket, 2008). Populasi penelitian ini yaitu seluruh mahasiswa perantau asal Papua yang sedang berkuliah di Kota Surabaya yang berdomisili di wilayah kota Surabaya Timur yang berjumlah 260 orang, pada penelitian ini terdapat batasan usia yaitu mahasiswa yang berusia 18 tahun sampai dengan usia 21 tahun, karena merujuk pada pengertian remaja menurut Badan Kependudukan dan Keluarga Berencana Nasional (BKKBN), mahasiswa yang diteliti hanya mahasiswa yang sedang berpacaran atau mahasiswa yang pernah berpacaran selama masa studi.

Penelitian ini menggunakan data yang tercatat oleh Ikatan Pelajar dan Mahasiswa Papua di Kota Surabaya. Data yang tercatat hanya berupa jumlah pelajar dan mahasiswa asal Papua di Kota Surabaya. Lokasi penelitian di lakukan di kota Surabaya, khususnya wilayah Surabaya Timur. Pengumpulan data penelitian dilakukan selama 4 minggu yaitu pada tanggal 20 Agustus hingga pada tanggal 22 September 2017. Sedangkan pengumpulan data lainnya akan dilakukan selama kurang lebih satu bulan sampai seluruh data yang dibutuhkan dalam penelitian ini terpenuhi.

Besar sampel pada penelitian ini ditentukan dengan rumus, Lemeshow (1991) yakni sebagai berikut: 


$$
n=\frac{\left(Z_{1-\frac{\alpha}{2}}\right)^{2} P(1-P) N}{d^{2}(N-1)+\left(Z_{1-\frac{\alpha}{2}}\right)^{2} P(1-P)}
$$

Berdasarkan rumus pengambilan besar sampel di atas, maka dapat dihitung besar sampel sebagai berikut:

$$
\begin{aligned}
& n=\frac{\left(Z_{1-\frac{\alpha}{2}}\right)^{2} P(1-P) N}{d^{2}(N-1)+\left(Z_{1-\frac{\alpha}{2}}\right)^{2} P(1-P)} \\
& n \\
& =\frac{(1,96)^{2} 0,40(1-0,40) 260}{(0,1)^{2}(260-1)+(1,96)^{2} 0,40(1-0,40)} \\
& n=68,25 \approx 70 \text { orang }
\end{aligned}
$$

Berdasarkan perhitungan rumus tersebut, maka didapatkan besar sampel minimal 70 mahasiswa perantau asal Papua yang berusia kurang dari sama dengan 21 tahun yang sedang berpacaran atau pernah berpacaran selama masa studi di Kota Surabaya.

Pengambilan sampel dalam penelitian ini menggunakan teknik sampel acak sederhana atau simple random sampling, teknik ini memperhatikan kerangka sampel yang dapat membedakan antara subyek penelitian yang satu dengan lainnya. Data yang telah terkumpul berdasarkan hasil data primer penilitian diolah menggunakan aplikasi komputer dengan program statistik. Uji statistik yang digunakan yaitu uji regresi logistik sederhana (simple logistic regression) yang digunakan untuk menyeleksi kandidat regresi logistik ganda yang akan diuji. Variabel independen yang menjadi kandidat ( $p$ kurang dari 0,25) akan diuji kembali dengan uji statistik regresi logistik ganda (multiple logistic regression) secara bersamaan sehingga dapat diketahui variabel independen yang berpengaruh terhadap variabel dependen yaitu status hubungan terhadap perilaku pacaran berisiko mahasiswa perantau asal Papua di Kota Surabaya.

\section{HASIL}

Responden dalam penelitian ini ialah mahasiswa/i perantau asal Papua yang sedang berkuliah di Kota Surabaya yang berdomisili di Wilayah Kecamatan Mulyorejo, Kecamatan Gubeng, Kecamatan Tambaksari dan Kecamatan Sukolilo. Mahasiswa/i yang menjadi responden merupakan remaja akhir yang ber-usia 18-21 tahun dan yang telah memenuhi kriteria inklusi yang telah ditetapkan oleh peneliti. Jumlah subyek penelitian. ini sebanyak 70 orang.

Berdasarkan Tabel 1 diketahui bahwa terdapat 70 responden mahasiswa yang terdiri dari $50 \%$ mahasiswa laki-laki dan $50 \%$ perempuan dengan tingkat pendidikan yang sama yakni 100\% mahasiswa perantau asal Papua sedang menempuh studi pada jenjang Sarjana (S1) pada tahun 2017. Usia responden minimal 18 tahun $(11,4 \%)$ dan maksimal 21 tahun $(50 \%)$. Sebagian besar mahasiswa yang sedang berpacaran dan berada di Kota yang sama $(65,7 \%)$, berpacaran jarak jauh $(15,7 \%)$ dan yang tidak sedang berpacaran $(18,6 \%)$. Variabel status hubungan berpacaran mempermudah penelitian yaitu untuk mengetahui kemungkinan responden melakukan pacaran berisiko, juga untuk melihat ada tidaknya hubungan antara status hubungan berpacaran dengan perilaku pacaran berisiko.

Sebaran karakteristik responden penelitian pada perilaku pacaran berisiko mahasiswa perantau asal Papua yang berada di wilayah Kota Surabaya Timur dapat dilihat pada Tabel 1. sebagai berikut

Berdasarkan Tabel 1. diketahui bahwa terdapat 70 responden mahasiswa yang terdiri dari 50\% mahasiswa laki-laki dan $50 \%$ perempuan dengan tingkat pendidikan yang sama yakni $100 \%$ mahasiswa perantau asal Papua sedang menempuh studi pada jenjang Sarjana (S1) pada tahun 2017. Usia responden minimal 18 tahun $(11,4 \%)$ dan maksimal 21 tahun (50\%). Sebagian besar mahasiswa yang 
berdomisili di Wilayah Timur Kota Surabaya tinggal di kos $(71,4 \%)$ yaitu kos putra atau kos putri yang memiliki aturan dan bukan kos bebas, sedang sisanya bertempat tinggal di Kos Campur (14,3\%) atau kos bebas tanpa aturan, Asrama $(7,1 \%)$ dan Kontrakan (7,1\%). Penelitian perilaku pacaran berisiko pada mahasiswa perantau asal Papua membutuhkan salah satu karakteristik yaitu status hubungan, status hubungan dalam penelitian ini untuk mengetahui kemungkinan responden melakukan pacaran berisiko, dan juga melihat ada tidaknya hubungan antara status hubungan dengan pacaran berisiko. Sebagian besar mahasiswa yang sedang berpacaran dan berada di Kota yang sama $(65,7 \%)$.

Tabel 1. Distribusi Variabel Independen dan Variabel Dependent Perilaku Pacaran Berisiko pada Mahasiswa Perantau Asal Papua di Kota Surabaya

\begin{tabular}{lcc}
\hline Variabel & Jumlah & $(\boldsymbol{n}=$ \\
& $\mathbf{7 0})$ & \\
\cline { 2 - 3 } & $\boldsymbol{N}$ & $\mathbf{\%}$ \\
\hline Usia & 8 & 11,4 \\
18 tahun & 12 & 17,1 \\
19 tahun & 15 & 21,4 \\
20 tahun & 35 & 50,0 \\
21 tahun & & \\
Jenis Kelamin & 35 & 50,0 \\
$\quad$ Laki- laki & 35 & 50,0 \\
Perempuan & & \\
Status Hubungan & 46 & 65,7 \\
$\quad$ Berpacaran & 13 & 18,6 \\
$\quad$ Tidak Berpacaran & 11 & 15,7 \\
$\quad$ Pacaran Jarak Jauh & & \\
Perilaku Pacaran & 51 & 72,9 \\
$\quad$ Berisiko & 19 & 27,1 \\
$\quad$ Tidak Berisiko & & \\
Niat Perilaku Pacaran & & \\
Berisiko & 35 & 50,0 \\
$\quad$ Rendah & 29 & 41,4 \\
$\quad$ Sedang & 6 & 8,6 \\
$\quad$ Tinggi & & \\
Tingkat Pengetahuan & 1 & 1,4 \\
$\quad$ Rendah & 15 & 21,4 \\
$\quad$ Sedang & 54 & 77,1 \\
$\quad$ Tinggi & & \\
$\quad$ &
\end{tabular}

\section{Variabel Usia}

Variabel usia responden dikategorikan berdasarkan kategori usia remaja, dimana remaja akhir dimulai pada usia 18-21 tahun, dan merupakan usia mahasiswa sarjana pada umumnya. Sebaran proporsi berdasarkan usia terhadap perilaku pacaran berisiko mahasiswa dapat dilihat pada Tabel 2 sebagai berikut;

Tabel 2. Distribusi Perilaku Pacaran Berisiko Berdasarkan Usia Mahasiswa Perantau Asal Papua di Kota Surabaya

\begin{tabular}{lcccccc}
\hline \multirow{2}{*}{ Usia Responden } & \multicolumn{2}{c}{$\begin{array}{c}\text { Penilaku Pacaran } \\
\text { Benisiko }\end{array}$} & $\begin{array}{c}\text { Perilaku Pacaran } \\
\text { Tidak Benikik }\end{array}$ & \multicolumn{2}{l}{ Jumlah } \\
\cline { 2 - 7 } & $n$ & $\%$ & $n$ & $\%$ & $n$ & $\%$ \\
\hline 18 & 5 & 62,5 & 3 & 37,5 & 8 & 100,0 \\
19 & 10 & 83,3 & 2 & 16,7 & 12 & 100,0 \\
20 & 11 & 73,3 & 4 & 36,7 & 15 & 100,0 \\
21 & 25 & 71,4 & 10 & 28,6 & 35 & 100,0 \\
\hline Jumlah & 51 & 72,9 & 19 & 27,1 & 70 & 100,0 \\
\hline
\end{tabular}

Berdasarkan hasil distribusi pada Tabel 2 diketahui bahwa proporsi responden di masing-masing usia yang melakukan pacaran berisiko yaitu usia 18 tahun (62,5\%), 19 tahun (83,3\%), 20 tahun $(73,3 \%)$, dan usia 21 tahun $(71,4 \%)$. Proporsi tertinggi remaja melakukan pacaran berisiko yaitu pada usia 21 tahun, dikarenakan $25(71,4 \%)$ dari $35(100 \%)$ mahasiswa pada usia 21 tahun telah melakukan pacaran berisiko. Sedangkan proporsi terendah mahasiswa melakukan pacaran berisiko terdapat pada 18 tahun yaitu $5(62,5 \%)$ dari $8(100 \%)$ usia 18 tahun yang melakukan pacaran berisiko. Berdasarkan hasil distribusi dapat disimpulkan bahwa risiko mahasiswa melakukan pacaran berisiko terdapat pada usia 21 tahun. Mahasiswa yang berusia 21 tahun sudah masuk pada masa remaja akhir, yaitu masa menuju dewasa. Masa dimana remaja merasa bahwa diri mereka sudah mampu bertanggungjawab dengan diri mereka sendiri. Pada usia ini juga remaja telah melalui banyak pengalaman, memiliki banyak pengetahuan dan 
kemampuan. Sehingga hal ini juga berdampak pada perilaku pacaran remaja usia 21 tahun. Remaja pada usia ini cenderung memiliki keinginan seksual yang lebih tinggi sehingga dapat memicu remaja melakukan perilaku pacaran berisiko.

\section{Variabel Jenis Kelamin}

Variabel jenis kelamin responden dikategorikan menjadi laki-laki dan perempuan. Sebaran reponden berdasarkan jenis kelamin terhadap perilaku pacaran berisiko mahasiswa dapat dilihat pada Tabel 3 sebagai berikut.

Tabel 3. Distribusi Perilaku Pacaran Berisiko Berdasarkan Jenis Kelamin Mahasiswa Perantau Asal Papua di Kota Surabaya

\begin{tabular}{|c|c|c|c|c|c|c|}
\hline \multirow{2}{*}{$\begin{array}{l}\text { Jenis Kelamin } \\
\text { Responden }\end{array}$} & \multicolumn{4}{|c|}{ Penilaku Pacaran Perilaku Pacaran } & \multicolumn{2}{|c|}{ Jumlah } \\
\hline & $n$ & $\%$ & $n$ & $\%$ & $n$ & $\%$ \\
\hline Laki-laki & 26 & 74,3 & 9 & 25,7 & 35 & 100,0 \\
\hline Perempuan & 25 & 71,4 & 10 & 28,6 & 35 & 100,0 \\
\hline Jumlah & & & & & & 100,0 \\
\hline & 51 & 12,9 & 19 & 7,1 & & \\
\hline
\end{tabular}

Berdasarkan hasil distribusi pada Tabel 3 diketahui bahwa proporsi responden yang berperilaku pacaran berisiko dengan jenis kelamin laki-laki $(74,3 \%)$ sedang yang berjenis kelamin perempuan (71,4\%). Perbandingan perilaku pacaran berisiko berdasarkan jenis kelamin tidak terlalu jauh, meski proporsi laki-laki lebih banyak yang melakukan perilaku pacaran berisiko dibanding perempuan. Jenis kelamin laki-laki lebih berisiko melakukan perilaku pacaran berisiko dibanding jenis kelamin perempuan. Hal ini juga sejalan dengan observasi peneliti selama melakukan pengumpulan data yang menunjukkan bahwa laki-laki lebih berani menunjukkan bahwa mereka sering melakukan perilaku pacaran berisiko, dan tidak malu mengakui hal tersebut.

\section{Variabel Status Hubungan}

Variabel status hubungan dikategorikan menjadi tiga yatu berpacaran atau mahasiswa yang sedang menjalin relasi dengan lawan jenis dan berada di kota yang sama yaitu Kota Surabaya selama masa studi, tidak berpacaran yaitu mahasiswa yang sedang tidak berpacaran namun pernah berpacaran selama masa studi, dan pacaran jarak jauh yaitu mahasiswa ang sedang menjalin relasi dengan lawan jenis namun berada di kota yang berbeda. Sebaran responden berdasarkan status hubungan responden terhadap perilaku pacaran berisiko mahasiswa perantau asal Papua dapat dilihat pada Tabel 4.

Tabel 4. Distribusi Perilaku Pacaran Berisiko Berdasarkan Status Hubungan Mahasiswa Perantau Asal Papua di Kota Surabaya

\begin{tabular}{|c|c|c|c|c|c|c|}
\hline \multirow{2}{*}{$\begin{array}{l}\text { Status Hubumgan } \\
\text { Responden }\end{array}$} & \multicolumn{2}{|c|}{$\begin{array}{l}\text { Perialalu Pacaran } \\
\text { Berisitio }\end{array}$} & \multicolumn{2}{|c|}{$\begin{array}{l}\text { Pertalaku Pacaran } \\
\text { Tidalk Berisitio }\end{array}$} & \multicolumn{2}{|c|}{ Jumleh } \\
\hline & $n$ & $\%$ & $n$ & $\%$ & n & $\%$ \\
\hline Berpacaral & 43 & 93,5 & 3 & 6.5 & 46 & 1000 \\
\hline Tidak Bempacaran & 4 & 30,8 & 9 & 69.2 & 13 & 100,0 \\
\hline Pacaran Jarak Jauh & 4 & 36,4 & 7 & 63,6 & 11 & 100,0 \\
\hline Jumlah & 51 & 72.9 & 19 & 27,1 & 70 & 100,0 \\
\hline
\end{tabular}

Berdasarkan hasil distribusi pada Tabel 4 diketahui bahwa proporsi responden yang melakukan pacaran berisiko dengan status sedang berpacaran $(93,5)$, yang tidak berpacaran dan melakukan pacaran berisiko $(30,8 \%)$, dan yang melakukan pacaran berisiko dengan pacaran jarak jauh $(36,4 \%)$. Artinya bahwa mahasiswa perantau asal Papua yang sedang berpacaran lebih banyak melakukan pacaran berisiko, sehingga status berpacaran berisiko terhadap perilaku pacaran. Hal ini sejalan dengan pengamatan peneliti saat melakukan pengumpulan data yakni banyak mahasiswa perantau asal Papua yang 
belum menikah tinggal bersama pasangan mereka.

\section{Variabel Niat Perilaku Pacaran}

Variabel niat perilaku pacaran ini dikategorikan berdasarkan niat responden melakukan hubungan seksual dengan pasangan. Niat perilaku pacaran di lihat dari faktor yang mendorong responden ingin melakukan hubungan seksual, sehingga niat perilaku pacaran tinggi ketika banyak responden yang ingin melakukan hubungan seksual dengan pasangan dan rendah jika sedikit yang ingin melakukan hubungan seksual dengan pasangan mereka. Semakin banyak alasan yang mendorong responden melakukan hubungan seksual dengan pasangan menunjukan semakin tinggi niat perilaku pacaran yaitu pacaran berisiko pada responden. Sebaran responden berdasarkan niat perilaku pacaran terhadap perilaku pacaran berisiko pada mahasiswa perantau asal Papua dapat dilihat pada Tabel 5 sebagai berikut.

Tabel 5. Distribusi Perilaku Pacaran Berisiko Berdasarkan Niat Perilaku Pacaran Berisiko Mahasiswa Perantau Asal Papua di Kota Surabaya

\begin{tabular}{lrrrrrr}
\hline \multirow{2}{*}{ Niat Perilaku } & \multicolumn{2}{c}{$\begin{array}{c}\text { Peilaku Pacaran } \\
\text { Benisiko }\end{array}$} & \multicolumn{2}{c}{$\begin{array}{c}\text { Perlaku Pacaran } \\
\text { Tidak Benisiko }\end{array}$} & \multicolumn{2}{l}{ Jumlah } \\
Pacaran Bensiko o & \multicolumn{1}{c}{$n$} & \multicolumn{1}{c}{$\%$} & $n$ & $\%$ & $n$ & $\%$ \\
\cline { 2 - 7 } & 20 & 57,1 & 15 & 42,9 & 35 & 100,0 \\
\hline Rendah & 26 & 89,7 & 3 & 10,3 & 29 & 100,0 \\
Sedang & 5 & 83,3 & 1 & 16,7 & 6 & 100,0 \\
Tingg & 51 & 72,9 & 19 & 27,2 & 70 & 100,0 \\
\hline Jumlah & & & & & &
\end{tabular}

Berdasarkan hasil distribusi pada Tabel. 5 diketahui bahwa proporsi responden perilaku pacaran berisiko dengan niat pacaran sedang $(89,7 \%)$ lebih banyak dibanding proporsi perilaku pacaran berisiko responden dengan niat tinggi $(83,3 \%)$ dan niat rendah $(57,1 \%)$. Mahasiswa perantau asal Papua tidak memiliki niat untuk berperilaku pacaran berisiko, hal ini dilihat dari hasil distribusi yang menunjukkan bahwa mahasiswa dengan niat tinggi hanya 5 orang $(83,3 \%)$. Sehingga niat perilaku pacaran berisiko seharusya tidak mempengaruhi perilaku pacaran berisiko pada mahasiswa perantau asal Papua di Kota Surabaya. Tetapi hal ini berbanding terbalik dengan kenyatan bahwa mahasiswa perantau asal Papua memiliki tingkat perilaku pacaran berisiko yang tinggi yaitu $72,9 \%$.

\section{Variabel Tingkat Pengetahuan}

Variabel tingkat pengetahuan responden dikategorikan menjadi tingkat pengetahuan kurang, tingkat pengetahuan sedang dan tingkat pengetahuann baik. Sebaran perilaku pacaran berisiko berdasarkan tingkat pengetahuan pada mahasiswa perantau asal Papua dapat dilihat pada Tabel 6 sebagai berikut.

Tabel 6. Distribusi Perilaku Pacaran Berisiko Terhadap Tingkat Pengetahuan Mahasiswa Perantau Asal Papua

\begin{tabular}{lrrrrrr}
\hline $\begin{array}{l}\text { Tingkat } \\
\text { Pengetahuan } \\
\text { Tentang Penlaku }\end{array}$ & $\begin{array}{c}\text { Perilaku Pacaran } \\
\text { Bensiko }\end{array}$ & $\begin{array}{c}\text { Penlaku Pacaran } \\
\text { Tidak Bensiko }\end{array}$ & \multicolumn{2}{l}{ Jumlah } \\
Pacaran Bensiko & $n$ & $\%$ & $n$ & $\%$ & $n$ & $\%$ \\
\hline Rendah & 1 & 100 & 0 & 0 & 1 & 100,0 \\
Sedang & 9 & 60 & 6 & 40 & 15 & 100,0 \\
Tingg & 41 & 75,9 & 13 & 24,1 & 54 & 100,0 \\
\hline Jumlah & 51 & 72,9 & 19 & 27,1 & 70 & 100,0 \\
\hline
\end{tabular}

Berdasarkan hasil distribusi pada Tabel 6 diketahui bahwa proporsi responden yang pacaran berisiko dengan tingkat pengetahuan tinggi $(75,9 \%)$ lebih banyak dari pada proporsi responden dengan tingakat pengetahuan sedang $(60 \%)$ dan kurang $(100 \% \%)$. Dapat disimpulkan bahwa mahasiswa memiliki pengetahuan yang baik mengenai seksualitas dan perilaku pacaran. Hasil distribusi menunjukan bahwa hanya 1 responden yang memiliki pengetahuan rendah dan memiliki perilaku pacaran yang berisiko, sehingga semakin tinggi tingkat pengetahuan maka semakin baik perilaku pacaran mahasiswa. Namun, berdasarkan hasil distribusi responden 
dengan tingkat pengetahuan tinggi juga memiliki perilaku pacaran yang berisiko.

\section{Hasil Uji Statistik}

Variabel independen yang diteliti akan diseleksi berdasarkan uji regresi logistik sederhana untuk memperoleh variabel kandidat regresi logistik gana. Hasil dari seleksi kandidat akan diuji berdasarkan uji regresi logistik ganda dan memperoleh model terbaik dalam menetukan determinan yang berpengaruh terhadap perilaku pacaran berisiko pada mahasiswa perantau asal Papua di Kota Surabaya. Hasil seleksi kandidat regresi logistik ganda berdasarkan uji regresi logistik sederhana ditampilkan pada Tabel 7, sebagai berikut;

Tabel 7. Hasil Seleksi Kandidat Regresi Logistik Ganda Berdasarkan Uji Regresi Logistik Sederhana

\begin{tabular}{|c|c|c|}
\hline $\begin{array}{c}\text { Variabel } \\
\text { Independen }\end{array}$ & $p$ & Keterangan \\
\hline $\begin{array}{l}\text { Status } \\
\text { Hubungan }\end{array}$ & 0,000 & Kandidat \\
\hline $\begin{array}{l}\text { Niat Perilaku } \\
\text { Pacaran }\end{array}$ & 0,249 & Kandidat \\
\hline Jenis kelamin & 0,788 & $\begin{array}{l}\text { Bukan } \\
\text { Kandidat }\end{array}$ \\
\hline Usia & 0,621 & $\begin{array}{l}\text { Bukan } \\
\text { Kandidat }\end{array}$ \\
\hline $\begin{array}{l}\text { Tingkat } \\
\text { Pengetahuan }\end{array}$ & 1,000 & $\begin{array}{l}\text { Bukan } \\
\text { Kandidat }\end{array}$ \\
\hline
\end{tabular}

Berdasarkan tabel diatas menunjukan bahwa variabel independen yang masuk kandidat regresi logistik ganda ( $p$ kurang dari 0,25 ) adalah status hubungan dan niat perilaku pacaran berisiko, sedangkan variabel lain yaitu usia, jenis kelamin, jenis tempat tinggal, peran orang tua, dan kepercayaan terhadap pasangan dinyatakan tidak berpengaruh terhadap perilaku pacaran berisiko pada mahasiswa perantau asal Papua karena nila $p$ lebih dari 0,25.
Uji regresi logistik ganda yang digunakan dalam pemilihan model, variabel yang menjadi kandidat berdasarkan uji regresi logistik sederhana dimasukkan semua ke dalam regresi logistik ganda dengan metode mengeliminasi secara bertahap variabel yang signifikansinya terbesar (Backward $L R$ ) hingga diperoleh model terbaik. Hasil uji regresi logistik ganda dapat dilihat pada tabel 8 sebagai berikut.

Tabel 8. Hasil Uji Regresi Logistik Ganda Berdasarkan Variabel Dependen dengan Variabel Independen

\begin{tabular}{cccc}
\hline Variabel Independen & $p$ & Rasio Risiko & Keterangan \\
\hline Status Hubungan & & & \\
$\begin{array}{c}\text { a. Berpacaran } \\
\text { b. Tidak berpacaran }\end{array}$ & 0,000 & 22,933 & $\begin{array}{c}\text { Berpengaruh } \\
\text { Kelompok } \\
\text { Pembanding }\end{array}$ \\
\hline Niat Perilaku Pacaran & 0,138 & - & $\begin{array}{c}\text { Tidak } \\
\text { Berpengaruh }\end{array}$ \\
\hline
\end{tabular}

Uji regresi logistik ganda merupakan uji statistik yang digunakan untuk mengetahui faktor yang mempengaruhi perilaku pacaran berisiko pada mahasiswa perantau asal Papua di Kota Surabaya. Berdasarkan hasil uji regresi logistik ganda menunjukan bahwa variabel independen yang terbukti secara statistik signifikan ( $p$ kurang dari 0,05) mempengaruhi perilaku pacaran berisiko pada mahasiswa perantau asal Papua di Kota Surabaya adalah status hubungan, sedangkan variabel independen lainnya yaitu usia, jenis kelamin, niat perilaku pacaran berisiko, tingkat pengetahuan tidak mempengaruhi perilaku pacaran berisiko pada mahasiswa perantau asal Papua di Kota Surabaya. Status hubungan yaitu status hubungan berpacaran. Status mahasiswa perantau asal Papua yang sedang berpacaran memiliki risiko terhadap perilaku pacaran berisiko pada remaja. Sedang status sedang tidak berpacaran tidak memiliki perngaruh terhadap perilaku pacaran berisiko pada mahasiswa perantau asal Papua di Kota Surabaya.Variabel independen yang secara 
statistik signifikan mempengaruhi perilaku pacaran berisiko pada mahasiswa perantau asal Papua yaitu status hubungan. Variabel status hubungan mahasiswa perantau asal Papua memiliki nilai $p$ sebesar 0,001 yang mana lebih besar dari 0,05 dengan nilai koefisien sebesar 22,933, yang berarti risiko mahasiswa melakukan pacaran berisiko yang sedang berpacaran sebesar 22,933 kali dari pada mahasiswa yang sedang tidak berpacaran.

\section{PEMBAHASAN}

Sebanyak 70 mahasiswa yang menjadi responden dalam penelitian ini dan memiliki karakterisik sebagian besar sedang berpacaran, karakteristik pacaran yang ditunjukkan oleh mahasiswa yaitu karakteristik pacaran bereiko yakni berciuman, melakukan gigitan cinta (cupang), saling meraba-raba organ sensitif pasangan, saling menggesekan kemaluan pada pasangan (petting), memasturbasi/dimasturbasi dan melakukan hubungan seksual. Hal ini sejalan dengan penelitian yang dilakukan Sekarrini (2012) yang mengkatergorikan perilaku seksual pada remaja menjadi dua yaitu perilaku seksual ringan dan perilaku seksual berat. Perilaku seksual ringan diantaranya yaitu mengobrol, nonton film, pegangan tangan, jalan-jalan, pelukan, sampai cium pipi, sedang perilaku seksual berat atau berisiko yaitu ciuman bibir, ciuman mulut, ciuman leher, meraba bagian tubuh sensitif, petting, masturbasi dan intercourse. Karakteristik lain pada responden diantaranya berjenis kelamin laki-laki dan perempuan, memiliki pengetahuan tinggi tentang perilaku pacaran berisiko, memiliki niat untuk melakukan perilaku pacaran berisiko (Harefa, 2013).

Hasil penelitian menunjukkan bahwa terdapat satu variabel independen yang mempengaruhi perilaku pacaran berisiko pada mahasiswa perantau asal Papua yaitu status hubungan. Hasil penelitian menunjukkan bahwa status hubungan berpengaruh terhadap perilaku pacaran berisiko pada mahasiswa perantau asal Papua di kota Surabaya. Kemungkinan mahasiswa melakukan perilaku pacaran berisiko dengan status berpacaran sebesar 25,083 kali lebih besar dibandingkan dengan mahasiswa yang memiliki perilaku pacaran berisiko dengan status tidak berpacaran dan pacaran jarak jauh.

Pacaran menjadi awal mula perilaku seksual seperti kissing, necking, petting, dan intercourse. Paul dan White mengatakan bahwa pacaran di masa remaja merupakan bagian dari proses sosialisasi, mempelajari keakraban dan memberi kesempatan untuk menciptakan relasi bermakna dan unik dengan lawan jenis, serta menjadi konteks untuk melakukan eksperimen dan eksplorasi seksual (Setiawan, 2008).

Hal ini sejalan dengan Data Survei Kesehatan Reproduksi Remaja Indonesia (SKRRI) tahun 2007 Pengalaman berpacaran remaja di Indonesia cenderung semakin berani dan terbuka. Remaja mulai berpegangan tangan, berciuman dan meraba/merangsang. Dalam survei juga diungkap $1 \%$ remaja perempuan dan $5 \%$ remaja laki-laki usia 15-24 tahun menyatakan pernah melakukan hubungan seksual pranikah, hasil tersebut juga menyatakan bahwa faktor yang mempengaruhi perilaku pacaran berisiko adalah mempunyai teman yang sedang berpacaran dan pengaruh teman yang pernah melakukan hubungan seksual dengan pacar (Umaroh, 2015).

Selain hai tersebut, hasrat seksual seseorang juga mempengaruhi terjadinya hubungan seksual. Menurut Sumiatin (2017) hasrat untuk melakukan hubungan seksual adalah timbulnya minat melakukan hubungan seksual. Hasrat seksual dapat timbul apabila tidak terjadi hambatan selesa seksual, hambatan gairah seksual, dan hambatan orgasme. Hasrat melakukan hubungan seksual dapat muncul kapan saja dan dimana saja. Keimanan seseorang juga mempengaruhi seseorang untuk mengendalikan hasrat seksual. Dalam 
penelitian Suwarni (2015) menyatakan bahwa iman yang lemah tidak dapat menolong remaja untuk menahan nafsu seksualnya. Kematangan iman seseorang menolong dirinya untuk menahan perilaku seksual yang progresif dan memunculkan rasa bersalah apabila melewati batas tertentu dalam perilaku seksual.

Kategori usia pada penelitian ini diukur berdasarkan definisi remaja menurut BKKBN yaitu remaja adalah seseorang yang belum menikah dan berusia 10-21 tahun. Responden dalam penelitian ini merupakan mahasiswa pada tahap remaja akhir yaitu 18-21 tahun. Masa remaja merupakan masa dimana seseorang mengalami perubahan baik secara fisik maupun psikis, fase persiapan menjadi dewasa. Kenyataan dilapangan menunjukkan bahwa terdapat mahasiswa yang menganggap diri mereka sudah mulai dewasa dan mandiri, hingga tidak mempertimbangkan usia dalam melakukan segala hal. Sehingga usia tidak berpengaruh terhadap perilaku pacaran mahasiswa, baik perilaku pacaran berisiko maupun tidak (Azinar, 2013).

Berdasarkan hasil penelitian diketahui bahwa sebagian besar mahasiswa yang merupakan remaja akhir banyak yang melakukan pacaran berisiko, namun hasil penelitian ini menunjukkan bahwa usia tidak berpengaruh terhadap perilaku pacaran berisiko mahasiswa perantau asal Papua di Wilayah Timur Kota Surabaya. Hal ini sejalan dengan penelitian Sekarrini (2012) yang meneliti remaja menengah dan mendapati tidak ada hubungan antara usia dengan perilaku seksual. Tidak adanya hubungan yang bermakna antara usia dengan perilaku pacaran berisiko ini sejalan dengan penelitian yang dilakukan Mahmudah dkk (2016).

Hasil penelitian menunjukkan bahwa jenis kelamin tidak berpengaruh terhadap perilaku pacaran berisiko pada mahasiswa perantau asal Papua di Wilayah Timur Kota Surabaya. Hasil penelitian menunjukkan bahwa jenis kelamin tidak berpengaruh terhadap perilaku pacaran berisiko pada mahasiswa perantau asal Papua di Wilayah Timur Kota Surabaya. Hal ini sejalan dengan penelitian yang dilakukan oleh Muliyati (2012) bahwa tidak ada hubungan yang signifikan antara jenis kelamin dengan perilaku pacaran berisiko. Penelitian yang dilakukan oleh Sekarrini (2012) juga menunjukkan bahwa tidak ada hubungan yang signifikan antara jenis kelamin dengan perilaku pacaran berisiko pada remaja. Pada penelitian ini faktor yang memungkinkan tidak adanya pengaruh yang signifikan antara jenis kelamin dan perilaku pacaran berisiko adalah status berpacaran, dimana responden merupakan mahasiswa yang sedang berpacaran, hingga perilaku pacaran berisiko dilakukan dengan pasangan mereka, yakni antara laki-laki dan perempuan. Dimana pasangan lakilaki melakukan aktivitas seksual yang diresponi oleh perempuan, sehingga baik laki-laki maupun perempuan, sama-sama menunjukkan perilaku seksual berisiko. Hal ini sejalan dengan penelitian yang dilakukan oleh Muliyati (2012) bahwa tidak ada hubungan yang signifikan antara jenis kelamin dengan perilaku pacaran berisiko.

Hasil penelitian menunjukkan bahwa niat perilaku pacaran tidak berpengaruh secara signifikan terhadap perilaku pacaran berisiko pada mahasiswa perantau asal Papua di Wilayah Timur Kota Surabaya. Teori Perilaku Berencana (TPB) menyatakan bahwa perilaku dipengaruhi oleh niat individu dalam melakukan sesuatu perilaku tertentu. Semakin kuat niat seseorang untuk terlibat dalam perilaku maka semakin besar kemungkinan perilaku tersebut dilakukan. Niat untuk melakukan suatu perilaku juga dipengaruhi oleh berbagai faktor yaitu sikap, norma subyektif dan pengendali perilaku. Hasil penelitian ini tidak sejalan dengan penelitian yang dilakukan oleh Purwanza, dkk (2017) yang menyatakan bahwa ada pengaruh antara niat perilaku seksual dan perilaku seksual. Juga penelitian yang dilakukan oleh Anniswah 
(2016), menyatakan bahwa niat berhubungan secara signifikan terhadap perilaku. Anniswah (2016)melakukan peneltian kualitatif, yang secara mendalam meneliti niat perilaku dari beberapa responden yang menunjukkan bahwa adanya hubungan antara niat perilaku pacaran berisiko dan perilaku pacaran berisiko. Kemungkinkan terjadi karena adanya faktor yang memacu berperilaku seksual berisiko. Niat untuk melakukan hubungan seksual pra nikah muncul secara tiba-tiba ketika berada bersama pasangan, dan ketika mereka mulai melakukan perilaku pacaran berisiko lainnya. Hal ini menunjukkan bahwa niat untuk melakukkan pacaran berisiko akan muncul ketika dipengaruhi oleh faktor yang secara langsung mempengaruhi niat responden dan pasangannya. Sehingga penelitian ini menunjukkan bahwa kurangnya niat mahasiswa perantau asal Papua melakukan pacaran berisiko dan tidak ada hubungan antar niat dengan perilaku pacaran berisiko (Yaunin, 2016).

Hasil penelitian menunjukkan bahwa tingkat pengetahuan mengenai seksualitas, tingkat pengetahuan terhadap perilaku pacaran berisiko tidak berpengaruh secara signifikan terhadap perilaku pacaran berisiko pada mahasiswa perantau asal Papua di Kota Surabaya. Pengetahuan mahasiswa perantau asal Papua berbanding terbalik dengan perilaku pacaran mereka, mahasiswa lebih banyak mengetahui namun banyak juga melakukan pacaran berisiko. Berdasarkan hasil penelitian responden memiliki pengetahuan yang sangat baik tentang perilaku pacaran berisiko. Sebagian besar mahasiswa mengetahui bentuk perilaku pacaran berisiko, mengetahui dampak perilaku pacaran berisiko bagi kesehatan, dan hal-hal yang berkatan dengan seksualitas. Pengetahuan mahasiswa perantau asal Papua berbanding terbalik dengan perilaku pacaran mereka, mahasiswa lebih banyak mengetahui namun banyak juga melakukan pacaran berisiko.
Hasil penelitian ini sejalan dengan penelitian yang dilakukan oleh Lestary (2011) yang menunjukkan bahwa tidak ada hubungan yang signifikan antara tingkat pengetahuan dan perilaku pacaran berisiko. Secara teori, pengetahuan memiliki hubungan positif dengan perilaku seksual, semakin baik pengetahuan remaja maka semakin rendah perilaku pacaran berisiko, dan sebaliknya. Jika terdapat kontradiksi terhadap suatu faktor maka ada faktor lain yang lebih besar pengaruhnya yang mengendalikan faktor. Pada penelitian ini terjadi kontradiksi karena responden yang memiliki perilaku pacaran berisiko sangat paham akan pengetahuan reproduksi (Agung, 2014).

\section{SIMPULAN}

Berdasarkan hasil analisis dan pembahasan, dapat disimpulkan sebagai berikut, hasil distribusi menunjukkan bahwa perilaku pacaran berisiko pada mahasiswa perantau asal Papua sebesar $72,9 \%$. Sedangkan $27,1 \%$ remaja yang berstatus sebagai mahasiswa yakni mahasiswa perantau asal Papua tidak berprilaku pacaran berisiko.

Mahasiswa perantau asal Papua yang menjadi responden dalam penelitian ini adalah remaja yang berstatus mahasiswa, dengan kisaran usia 18-21 tahun, berstatus sedang berpacaran, pacaran jarak jauh, dan sedang tidak berpacaran meskipun pernah berpacaran selama masa studi. Mahasiswa perantau asal Papua memiliki tingkat pengetahuan yang tinggi terhadap perilaku seksual khususnya perilaku pacaran berisiko dan tidak memiliki niat untuk melakukan pacaran berisiko.

Determinan perilaku pacaran berisiko pada mahasiswa perantau asal Papua yaitu status hubungan pacaran mahasiswa, yakni status berpacaran. Mahasiswa perantau asal Papua yang berstatus sedang berpacaran memiliki pengaruh yang signifikan terhadap perilaku pacaran berisiko. Dengan nilai $p$ 
sebesar 0,001 yang mana lebih besar dari 0,05 dengan nilai koefisien sebesar 22,933, yang berarti risiko mahasiswa melakukan pacaran berisiko yang sedang berpacaran sebesar 22,933 kali dari pada mahasiswa yang sedang tidak berpacaran.

Variabel lain yaitu usia, jenis kelamin, niat perilaku pacaran berisiko, tingkat pengetahuan tidak berpengaruh terhadap perilaku pacaran berisiko pada mahasiswa prantau asal Papua di Kota Surabaya.

\section{DAFTAR PUSTAKA}

Agung, A., Agung, P., R., Wayan, N., Wulan, C., \& Putri, S. (2014). Hubungan Antara Jenis Kelamin Dan Status Sosioekonomi Keluarga Terhadap Seks Pranikah Pada Remaja SMA / Sederajat Di Wilayah Kerja Puskesmas Sukawati I Pada Tahun 2014.

Anniswah, N. (2016). Faktor-Faktor Yang Berhubungan Dengan Perilaku Seksual Berisiko IMS Pada Remaja Pria Di Indonesia. https://doi.org/10.1017/CBO97811 07415324.004

Azinar, M. (2013). Perilaku Seksual Pranikah Berisiko Terhadap Kehamilan Tidak Dinginkan. Jurnal Kesehatan Masyarakat, 8(2), 153-160. https://doi.org/10.15294/kemas.v8i 2.2639

Angket, K. (2008). METODE PENELITIAN A . Jenis Penelitian B . Metode Pengumpulan Data C . Populasi dan Sampel, 27-32.

Badan Pusat Statistik, Badan Koordinasi Keluarga Berencanan Nasional, Departemen Kesehatan, Macro International, Badan Pusat Statistik Indonesia, Menua, Iba, P. (2015). Kualitas Sumber Daya Manusia Dalam Menggapai Bonus Demografi Rachmawati Madjid. Jurnal Populasi, 2(1), 102-114. https://doi.org/2101018
Badan Pusat Statistik, Badan Koordinasi Keluarga Berencanan Nasional, Departemen Kesehatan, \& Macro International. (2013). Survei Demografi dan Kesehatan Indonesia 2012. SDKI, 16. https://doi.org/10.1111/j.14710528.2007.01580.x

Chandra, N. (2012). Gambaran Perilaku Seksual Remaja Di Sekolah Menengah Kejuruan (SMK) Swasta X2 di Kota Depok Tahun 2012

Giyai, M. (2017). Analisis Perilaku Seksual Pada Mahasiswa Papua Di Surabaya. Jurnal Kesehatan Masyarakat

Harefa Y, N. (2013) 'Studi Kualitatif Perilaku Seks Pranikah Remaja Putri Di Kota Gunungsitoli Tahun 2013', repository USU, pp. 1-67. doi:

10.1017/CBO9781107415324.004.

Hidayangsih, P. S. (2014). Perilaku Berisiko Dan Permasalahan Kesehatan Reproduksi Pada Remaja. Jurnal Kesehatan Reproduksi, 5(2), 1-10. https://doi.org/10.22435/KESPRO. V5I2.3886.89-101

Kementerian Kesehatan RI. (2015). Sexual Health Reproductiv; Situasi kesehatan Reproduksi remaja. Pusat Data Dan Informasi Kementerian Kesehatan RI.

Kementerian Kesehatan (2015) Profil Kesehatan Indonesia 2014, Kementerian Kesehatan Republik Indonesia. doi: 10.1037/00223514.51.6.1173.

Kusuma Dewi Pujianti, (2012), Gambaran Faktor-Faktor Risiko Perilaku Seksual Remaja SMA di Wilayah Kerja Puskesmas Halmahera Kota Semarang Tahun 2012. Skripsi.

Lestary, H., \& Sugiharti. (2011). Perilaku Berisiko Remaja Di Indonesia Menurut Survey Kesehatan Reproduksi Remaja Indonesia (SKRRI) Tahun 2007. Jurnal 
Kesehatan Reproduksi, 1(3), 136144.

Lestari, I. A. (2014). Faktor-Faktor Yang Berhubungan Dengan Perilaku Seks Pranikah Pada Mahasiswa Unnes. Unnes Journal of Public Health, 3(4), 27-38.

Mahmudah, U., Cahyati, W. H., \& Wahyuningsih, A. S. (2013). Jurnal Kesehatan Masyarakat, 8(2), 113-120. https://doi.org/ISSN 1858-1196

Muliyati. (2012). Faktor- Faktor yang Berhubungan dengan Perilaku Gaya Pacaran pada Siswa SMU X dan MAN Y Kabupaten Sidrap Provinsi Sulawesi Selatan Tahun 2012.

Riskesdas (2013), Riset Kesehatan Dasar, Badan Penelitian dan Pembangunan Kesehatan tentang Perilaku Seksual Remaja.

Rosdarni, Dasuki, D., \& Waluyo, S. D. (2015). Pengaruh Faktor Personal terhadap Perilaku Seksual Pranikah pada Remaja. Jurnal Kesehatan Masyarakat Nasional, 9(3), 214221.

https://doi.org/10.21109/kesmas.v9 i3.567

SDKI (2012), Survei Demografi Kesehatan Indonesia tentang Kesehatan Reproduksi Remaja.

Sekarrini. (2012). Faktor-Faktor Yang Berhubungan Dengan Perilaku Reksual Remaja Di SMK Kesehatan Di Kabupaten Bogor Tahun 2011. Skripsi. Depok: Fakultas Kesehatan Masyarakat UI.

Setiawan, R., \& Nurhidayah, S. (2008).
Pengaruh pacaran terhadap perilaku seks pranikah. Jurnal Soul, 1(2), 59-7

Sumiatin, T., Purwanto, H., \& Ningsih, W. T. (2017). Pengaruh Persepsi Remaja Tentang Perilaku Seks Terhadap Niat Remaja Dalam Melakukan Perilaku Seks Berisiko. Jurnal Keperawatan, 8(1), 96-101.

Suwarni, L., \& Selviana. (2015). Inisiasi Seks Pranikah Remaja dan Faktor yang Mempengaruhi. Jurnal Kesehatan Masyarakat, 10(2), 113-120.

https://doi.org/10.15294/kemas.v10 i 2.3378

Syamsiah, S. (2007). Hubungan Pengetahuan dan Sumber Informasi Siswa Tentang Kespro Remaja Dengan Sikap Siswa Terhadap Seks Bebas.

Tri Sulastri Lesteri (2015), Perubahan Perilaku Pacaran Remaja Sekolah Menengah Pertama Negeri 2 Sendawar Di Kutai Barat, Mahasiswa Program S1 SosiatriSosiologi, Fakultas Ilmu Sosial dan Ilmu Politik, Universitas Mulawarman.

Umaroh, ayu khoirul. (2015). Hubungan antara faktor internal dan eksternal dengan perilaku seksual pranikah remaja indonesia. Jurnal Kesehatan Masyarakat Andalas, $10,65-75$.

Yaunin, Y., \& Lestari, Y. (2016). Artikel Penelitian Faktor-Faktor yang Berhubungan dengan Perilaku Seksual Remaja di Kota Padang. Jurnal FK Unand, 5(2), 448-455. 